\section{Implications of Mating Behavior in Watermelon Breeding}

\author{
Rakesh Kumar', Mahendra Dia, and Todd C. Wehner \\ Department of Horticultural Science, Kilgore Hall, Box 7609, North Carolina \\ State University, Raleigh, NC 27695-7609
}

Additional index words. Citrullus lanatus, intercrossing, inbreeding, pollination, pedigree breeding, recurrent selection

\begin{abstract}
Understanding the natural mating behavior (self- or cross-pollination) in watermelon is important to the design of a suitable breeding strategy. The objective of this study was to measure the rate of self- and cross-pollination in watermelon [Citrullus lanatus (Thunb.) Matsum. \& Nakai] using the dominant gene $S p$ (Spotted leaves and fruit) as a marker. The experiment consisted of two studies and was a split plot in a randomized complete block design with 3 years (2009 to 2011) and four locations (Clinton, Kinston, Oxford, Lewiston, NC). For the intercrossing study, whole plots were the two spacings $(1.2 \times 0.3 \mathrm{~m}$ and $1.2 \times 0.6 \mathrm{~m})$ with four replications in 2010 . For the inbreeding study, whole plots were two equidistant spacings $(3 \times 3 \mathrm{~m}$ and $6 \times 6 \mathrm{~m})$ with four replications in 2009 to 2011. Cultivars Allsweet and Mickylee were subplots within each whole plot. In the inbreeding study, spacing and year had a significant effect on the rate of self-pollination, which was moderate $(47 \%$ and $54 \%$, respectively) when watermelon plants were trained in a spiral and spaced $3 \times 3 \mathrm{~m}$ or $6 \times 6 \mathrm{~m}$ apart. Spacing and cultivar did not have a significant effect on cross-pollination in the intercrossing study. Closely spaced watermelon plants $(1.2 \times 0.3 \mathrm{~m}$ and $1.2 \times 0.6 \mathrm{~m}) \mathrm{had}$ low natural outcrossing rate $(31 \%$ and $35 \%$, respectively) and was not adequate to intercross families. However, breeders should consider the amount of self-pollination in watermelon to calculate the estimates of component of genetic variances.
\end{abstract}

Watermelon [Citrullus lanatus (Thunb.) Matsum. \& Nakai var. lanatus] has been improved for yield and other traits as part of the process of plant breeding. Knowledge of the rate (percentage) of self- or cross-pollination is useful for watermelon breeders interested in planning isolation distances, estimating components of genetic variance, or selecting among progenies produced through openpollination. In cross-pollinated crops, it is often assumed that individuals produced from a single parent are half-sib families and those genetic variances should be calculated on that assumption. However, variances may be improperly estimated if there is natural self-pollination (inbreeding). In addition, knowledge of the rate of natural self- or crosspollination in crops is useful in designing experiments for genetic studies, crop improvement, and for maintaining elite inbred lines (Chowdhury and Slinkard, 1997).

Studies of several crops, including barley (Hordeum vulgare L.), lima bean (Phaseolus lunatus L.), wild oat (Avena fatua L.), and rose clover (Trifolium hirsutum All.), all assumed to be predominantly self-pollinating species, have shown that even low outcrossing rates of $1 \%$ to $10 \%$ had a significant effect on the genetic structure of the populations (Harding and Tucker, 1964; Jain, 1976). Crop

Received for publication 26 Apr. 2013. Accepted for publication 14 June 2013.

We gratefully acknowledge Ms. Tammy Ellington for assistance with the field tests.

${ }^{1}$ To whom reprint requests should be addressed; e-mail rakesh.kumar@syngenta.com. improvement methods for self-pollinated crops are different from those of cross-pollinated crops (Fehr, 1993). Common methods for crop improvement used in watermelon are pedigree breeding and recurrent selection (Wehner, 2008). Breeders often work with large $\mathrm{F}_{2}$ populations to recover improved trait combinations for individual plant selections using pedigree breeding. In cross-pollinated crops, controlled self-pollination is made on individual plants by covering flowers before they open, requiring resources for each population and family to be advanced. If the rate of self-pollination can be increased in the field, watermelon breeders can harvest openpollinated seeds from individual plant selections in early generations. On the other hand, if the rate of natural outcrossing can be increased, watermelon populations can be improved by recurrent selection by using natural intercrossing of selected families in isolation blocks (Kumar and Wehner, 2011). Intercrossing can play an important role in genetic gain (Wehner and Cramer, 1996).

Crop species are classified as autogamous, allogamous, or mixed mating types. Watermelon is predominantly an allogamous species with monoecious or andromonoecious flowering habit (Ferreira et al., 2002). The $a$ locus determines sex expression in watermelon, producing monoecious $(A A)$ or andromonoecious ( $a a$ ) sex expression (Guner and Wehner, 2004; Martin et al., 2009; Rhodes and Dane, 1999; Rhodes and Zhang, 1995). Monoecious sex expression promotes allogamy, whereas andromonoecious sex expression can promote autogamy (Martin et al., 2009). Cucurbits often grow as single plants or small populations in the wild. That leads to inbreeding and selection against inbreeding depression as well as the elimination of deleterious recessive alleles (Allard, 1999). In previous studies, there is no significant inbreeding depression measured in watermelon (Wehner, 2008). Further support for that was provided by Ferreira et al. (2000, 2002) who reported an inbreeding coefficient as high as 0.41 and outcrossing rate of $65 \%$ in andromonoecious families of watermelon and $77 \%$ averaged over monoecious and andromonoecious families. Thus, although watermelon is assumed to be a cross-pollinated crop, there is significant self-pollination that breeders should be aware of. Natural selfpollination can be of some use in a low-resource breeding program.

Pollination in watermelon is mediated by honeybees (Apis mellifera L.) and bumblebees (Bombus impatiens Cresson) that visit flowers to collect pollen and nectar (Delaplane and Mayer, 2000; Free, 1993; McGregor, 1976). The movement of honeybees and bumblebees among flowers in a field is directional, within rows rather than across rows (Cresswell et al., 1995; Handel, 1982; Walters and Schultheis, 2009; Zimmerman, 1979). The directional movement of pollinators within rows may reduce the revisits of flowers and maximize foraging efficiency (Collevatti et al., 2000).

Watermelon breeders often use $3 \times 3-\mathrm{m}$ spacing when working with single-plant hills in their breeding program (Neppl and Wehner, 2001). The $3 \times 3-\mathrm{m}$ plant spacing provides good separation of vines for pollination and selection. Walters and Schultheis (2009) reported that watermelon plants were mostly self-pollinated when spaced more than $10 \mathrm{~m}$ apart. However, 10-m hill spacing may not be economical in breeding programs that handle thousands of plants per year. It might be possible to manipulate the mating behavior (pollination) of watermelon plants by optimizing plant spacing. Furthermore, close plant spacing may be used to enhance crosspollination, thus facilitating intercrossing among families in a recurrent selection program. Recurrent selection is predominantly used to improve quantitative traits (Hallauer and Miranda, 1988). On the other hand, increasing the plant spacing might increase the amount of self-pollination for individual plant selection where required in methods such as pedigree breeding.

The environment affects pollen flow in cucurbit crops which, in turn, affects the rate of self- or cross-pollination (Gingras et al., 1999; Stanghellini and Schultheis, 2005). Variation in wind velocity, humidity, light intensity, temperature, and other environmental factors over years and locations may influence pollinator behavior and sex expression in watermelon and thus affect the rate of self-pollination (Kalbarczyk, 2009; Robinson and Decker-Walters, 1997). Self-pollination has been reported to vary from $23 \%$ to $77 \%$ over locations in cucumber (Wehner and Jenkins, 1985). Jenkins (1942) reported 30\% to $35 \%$ natural self-pollination in cucumber. 
Hence, it is useful to study the rate of selfor cross-pollination over multiple years and locations.

In tomato and watermelon, cultivars differ in their ability to produce pollen (Lesley, 1924; Stanghellini and Schultheis, 2005). Pollination may be affected by the amount of pollen produced by the flowers of a particular cultivar. The availability of more pollen to the pollinators may increase the rate of outcrossing. The mating behavior in watermelon depends on environment, cultivar, and flight pattern of pollinators. However, we were interested in those aspects of mating behavior (pollination) that are under the control of the plant breeder. The objective of this study was to determine the rate of self- or crosspollination in watermelon as affected by spacing, year, location, and cultivar.

\section{Materials and Methods}

The experiment was conducted at research stations in North Carolina: Horticultural Crops Research Station, Clinton; Cunningham Research Station, Kinston; Peanut Belt Research Station, Lewiston; and Oxford Tobacco Research Station, Oxford, in 3 years (2009 to 2011). Standard horticultural practices were used as recommended by the North Carolina Extension Service (Sanders, 2004).

Treatment plots. The experiment consisted of two studies: inbreeding study in 2009 to 2011 and intercrossing study in 2010 . The objective of the inbreeding study was to determine if wide spacing increased the amount of self-pollination sufficiently for single-plant selection in early generations for methods such as pedigree breeding. In contrast, the goal of the intercrossing study was to determine if close plant spacing increased the rate of cross-pollination for use in intercrossing families for recurrent selection. The inbreeding study was a split plot in a randomized complete block design with two blocks of two repetitions (within block) at each of two locations (Kinston and Clinton, NC) in 2009 to 2011 (Fig. 1). Spacings of $3 \times$ $3 \mathrm{~m}$ (3-m row spacing with $3-\mathrm{m}$ hill spacing) and $6 \times 6 \mathrm{~m}(6-\mathrm{m}$ row spacing with $6-\mathrm{m}$ hill spacing) were used in this experiment as whole plot treatments. The $3 \times 3-\mathrm{m}$ spacing is often used by breeders in the United States (Neppl and Wehner, 2001). We were interested in the common $3 \times 3-\mathrm{m}$ spacing as well as wider plant spacing, $6 \times 6 \mathrm{~m}$. Wider spacing than $6 \times 6 \mathrm{~m}$ might not be too economical to use in breeding program.

The intercrossing study was also a split plot in a randomized complete block design planted at Oxford (north side), Oxford (south side), Rocky Mount, and Lewiston in North Carolina in 2010 (Fig. 2). Each of the four locations had one replication. Whole plot treatments were the two in-row spacings: $1.2 \times 0.3 \mathrm{~m}(1.2-\mathrm{m}$ row spacing with $0.3-\mathrm{m}$ hill spacing) and $1.2 \times 0.6 \mathrm{~m}(1.2-\mathrm{m}$ row spacing with $0.6-\mathrm{m}$ hill spacing). The objective of this study was to determine if close spacing leads to adequate cross-pollination among plants for intercrossing families in a recurrent selection program. An additional objective of both studies was also to generate information about self-pollination of watermelon at different plant spacings. Watermelon is assumed to be a cross-pollinated crop; hence, estimates of genetic variances are calculated on that assumption. Estimates are biased if there is inbreeding (selfpollination) in the breeding population.

In both studies, 'Allsweet' and 'Mickylee' were subplot treatments in the whole plot treatment (spacings). The seeds (progeny) harvested from 'Allsweet' and 'Mickylee' were planted to measure the rate of self- or cross-pollination. 'Moon and Stars' was planted next to plants of 'Allsweet' and 'Mickylee' as the pollen donor because it had the spotted $(S p)$ marker gene. The in-row spacing was defined as the distance between pollen acceptor, 'Allsweet' and 'Mickylee', and the pollen donor, 'Moon and Stars'. 'Moon and Stars' has large, elongate fruit, a dark green rind with yellow spots, and firm, sweet flesh with dotted seeds. The dominant trait of bright yellow spots on the rind and leaves is dominant to the recessive trait of uniformgreen rind and foliage color and is the result of a single dominant gene, $S p$ (Guner and Wehner, 2004; Poole, 1944; Rhodes, 1986). The $S p$ gene was used as a marker to measure outcrossing, as observed in the progeny of 'Allsweet' and 'Mickylee'. 'Allsweet' has large, elongate fruit with a striped rind and 'Mickylee' has small, round fruit with a gray rind (Wehner, 2002). Both of these cultivars have uniform green foliage $(s p)$ and represent two different groups of cultivars.

\section{Single treatment plot in inbreeding study}

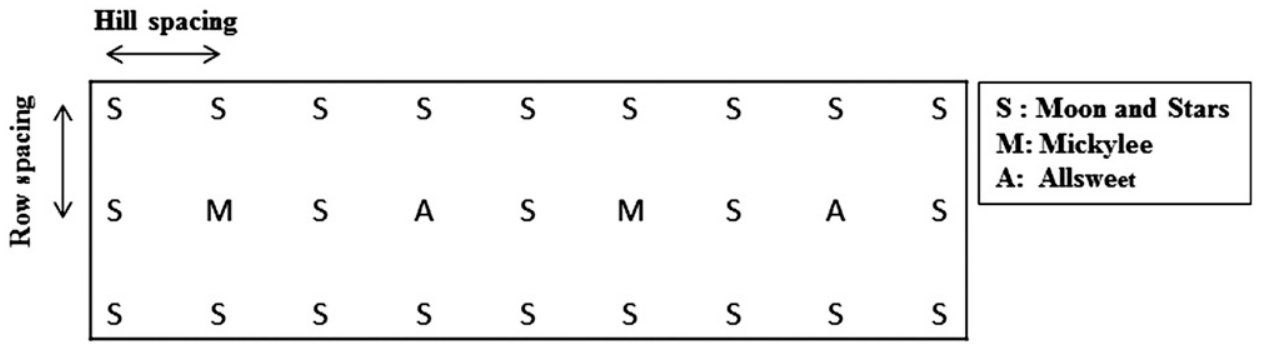

Fig. 1. Experiment design showing an arrangement of a treatment plot in inbreeding study in 2009-11. The experiment was a split plot in a randomized complete block design with two blocks of two repetitions (within block). Whole plot treatments were the two in-row spacings: $3 \times 3 \mathrm{~m}(3-\mathrm{m}$ row spacing with 3 -m hill spacing) and $6 \times 6 \mathrm{~m}(6-\mathrm{m}$ row spacing with 6-m hill spacing). 'Allsweet' (A) and 'Mickylee' (M) were two subplot treatments within each in-row spacing. 'Moon and Stars' (S) was planted next to plants of 'Allsweet' and 'Mickylee' as the pollen donor because it had the spotted (Sp) marker gene.

Single treatment plot in intercrossing study

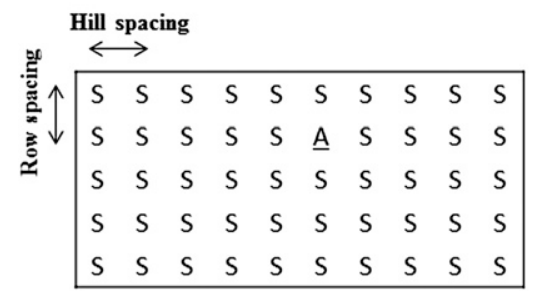

\begin{tabular}{|llllllllll|l|}
\hline S & S & S & S & S & S & S & S & S & S & S: Moon and Stars \\
S & S & S & S & S & S & S & S & S & S & M: Mickylee \\
S & S & S & S & S & S & S & S & S & S & \\
S & S & S & S & M & S & S & S & S & S & \\
S & S & S & S & S & S & S & S & S & S \\
\hline
\end{tabular}

Fig. 2. Experiment design showing a replication of treatment plots in intercrossing study in 2010. The experiment was a split plot in a randomized complete block design with four replications (four locations had one replication each). Whole plot treatments were the 2 in-row spacings: $1.2 \times 0.3 \mathrm{~m}(1.2$-m row spacing with 0.3-m hill spacing) and $1.2 \times 0.6 \mathrm{~m}(1.2-\mathrm{m}$ row spacing with $0.6-\mathrm{m}$ hill spacing). 'Allsweet' (A) and 'Mickylee' (M) were two subplot treatments within each in-row spacing. 'Moon and Stars' (S) was planted next to plants of 'Allsweet' and 'Mickylee' as the pollen donor because it had the spotted (Sp) marker gene. 
Transplants were grown in 72-cell polyethylene flats in the greenhouse of North Carolina State University in Raleigh, NC. A 4P Fafard soilless mix (Conrad Fafard Incorporated, Agawam, MA) was used in the flats. The transplants were moved to coldframes when they were 4 weeks old and transplanted to the field after 1 week of acclimation. Transplants were planted on raised, shaped beds covered with black plastic mulch. Fertilizer was incorporated before planting as a mix including ammonium nitrate at a rate of $90 \mathrm{~kg} \cdot \mathrm{ha}^{-1}$ nitrogen $(\mathrm{N})$, $39 \mathrm{~kg} \cdot \mathrm{ha}^{-1}$ phosphorus, and $74 \mathrm{~kg} \cdot \mathrm{ha}^{-1}$ potassium with an additional $40 \mathrm{~kg} \cdot \mathrm{ha}^{-1} \mathrm{~N}$ (as sodium nitrate) applied at the vine tipover stage. Soil was fumigated with mixture of 1,3-dichloropene and chloropicrin applied at a rate of $60 \mathrm{~L} \cdot \mathrm{ha}^{-1}$. Irrigation was applied in a drip irrigation system for a total of 25 to $40 \mathrm{~mm}$ per week. Rows were 1.2, 3, or $6 \mathrm{~m}$ apart (center to center). For the inbreeding study, plants were trained in a spiral arrangement each week starting when the vines reached the edge of the raised bed and ending at the time of fruit set (Gusmini and Wehner, 2007). For the intercrossing study, no spiral training was practiced to encourage cross-pollination. Honeybees were placed in the field at the stage of first flower opening using the recommended rate of two active hives per ha. No disease problems were observed.

Progeny evaluation plots. Progenies were evaluated from seeds obtained from treatment plots grown in the spring season each year and planted in the summer season. One ripe fruit was harvested from each singleplant hill of 'Allsweet' and 'Mickylee' in each treatment combination. Progeny evaluation plots were $1.5 \times 5.2 \mathrm{~m}$. Progeny were evaluated at the four true-leaf stage using 100 plants per plot to calculate the rate of selfand cross-pollination. A second evaluation was done 2 weeks after the first to confirm the results.

All seeds in the fruit that were set on 'Allsweet' and 'Mickylee' were produced through a combination of self- and crosspollination. Progeny with bright yellow spots on their leaves were the result of crosspollination by 'Moon and Stars' carrying the $S p$ allele. The rate of self-pollination was measured as the percentage of uniform (nonspotted) plants out of the total. The data were analyzed using the MEANS and GLM procedures of SAS (SAS Institute, Inc., Cary, NC). Means were separated using least significant difference $(P \leq 0.05)$ for those factors having a significant $F$ ratio in the analysis of variance. Data were means of four locations in the intercrossing study and two locations and two blocks within each location in the inbreeding study. Data were analyzed separately for the inbreeding study and the intercrossing study.

\section{Results}

Inbreeding study (2009-11). The rate of self-pollination was studied only at wide spacings of $3 \times 3 \mathrm{~m}$ (3-m row spacing with $3-\mathrm{m}$ hill spacing) and $6 \times 6 \mathrm{~m}(6-\mathrm{m}$ row spacing with 6-m hill spacing) in multiple environments. Year of testing and spacing had a strong effect $(P \leq 0.05)$ on the rate of self-pollination (Table 1). Location and cultivar did not affect the rate of self-pollination. There were no interactions $(P \geq 0.05)$ among spacing, year, location, or cultivar. This indicated row spacings, years, cultivars, and locations were consistent and independent in their effects. Data were presented by spacing, cultivar, location, and year (Table 2).

The rate of self-pollination was comparable in 2009 and 2011, whereas it was lower in 2010 at Clinton and Kinston compared with 2009 and 2011 (Table 2). In 2010, the rate of self-pollination was as low as $16 \%$ at $3 \times 3-\mathrm{m}$ and $21 \%$ at $6 \times 6-\mathrm{m}$ spacing in Clinton. The mean rate of self-pollination was $38 \%$ higher in 2009 and $35 \%$ higher in 2011 compared with 2010. Large variations in the rate of selfpollination are possible over years. There was $7 \%$ more self-pollination when plants were spaced at $6 \times 6 \mathrm{~m}$ compared with $3 \times 3 \mathrm{~m}$. However, the rate of self-pollination $(47 \%$ and 54\%) at both spacings was not close to what is found in self-pollinated crops ( $95 \%$ or greater).

Intercrossing study (2010). The intercrossing study was conducted in a single year
Table 1. Analysis of variance F-tests for the rate of self- or cross-pollination in watermelon at different research stations, North Carolina, in the springs of 2009 to 2011 in a split plot in a randomized complete block design where inrow spacing was whole plot and cultivar was the subplot treatment.

\begin{tabular}{|c|c|c|c|}
\hline Source of variation & $\mathrm{df}$ & MS & $P$ value \\
\hline \multicolumn{4}{|c|}{ Intercrossing study (2010) } \\
\hline Replication (R) & 3 & 1013 & 0.3585 \\
\hline Spacing $(\mathrm{S})$ & 1 & 52 & 0.7995 \\
\hline Cultivar (C) & 1 & 914 & 0.3195 \\
\hline $\mathrm{S} \times \mathrm{C}$ & 1 & 175 & 0.6453 \\
\hline Residual error & 10 & 709 & \\
\hline \multicolumn{4}{|c|}{ Inbreeding study (2009-11) } \\
\hline Year $(Y)$ & 2 & 6883 & 0.0003 \\
\hline Location (L) & 1 & 23 & 0.7210 \\
\hline $\mathrm{Y} \times \mathrm{L}$ & 2 & 514 & 0.1180 \\
\hline Block $(\mathrm{B})(\mathrm{Y} \times \mathrm{L})$ & 6 & 165 & 0.4366 \\
\hline $\mathrm{S}$ & 1 & 734 & 0.0450 \\
\hline $\mathrm{S} \times \mathrm{Y}$ & 2 & 186 & 0.2748 \\
\hline $\mathrm{S} \times \mathrm{L}$ & 1 & 54 & 0.5187 \\
\hline $\mathrm{S} \times \mathrm{Y} \times \mathrm{L}$ & 2 & 48 & 0.6749 \\
\hline $\mathrm{B}(\mathrm{S} \times \mathrm{Y} \times \mathrm{L})$ & 6 & 115 & 0.6252 \\
\hline Cultivar (C) & 1 & 5 & 0.8594 \\
\hline $\mathrm{S} \times \mathrm{C}$ & 1 & 315 & 0.1812 \\
\hline $\mathrm{C} \times \mathrm{Y}$ & 2 & 234 & 0.2617 \\
\hline $\mathrm{C} \times \mathrm{L}$ & 1 & 389 & 0.1406 \\
\hline $\mathrm{C} \times \mathrm{Y} \times \mathrm{L}$ & 2 & 131 & 0.4537 \\
\hline $\mathrm{S} \times \mathrm{C} \times \mathrm{Y}$ & 2 & 220 & 0.2812 \\
\hline $\mathrm{S} \times \mathrm{C} \times \mathrm{L}$ & 1 & 427 & 0.1247 \\
\hline $\mathrm{S} \times \mathrm{C} \times \mathrm{Y} \times \mathrm{L}$ & 2 & 37 & 0.7923 \\
\hline Residual error & 11 & 154 & \\
\hline
\end{tabular}

Table 2. The rate of self-pollination in watermelon with different spacings, cultivars, locations, and years in the environment study $(2009-11) .^{\mathrm{z}}$

\begin{tabular}{|c|c|c|c|c|c|}
\hline \multirow[b]{2}{*}{ Treatment } & \multirow[b]{3}{*}{ Location } & \multicolumn{4}{|c|}{ Self-pollination over years } \\
\hline & & 2009 & 2010 & 2011 & Overall mean by spacing \\
\hline Plot size & & \multicolumn{4}{|c|}{$(\%)$} \\
\hline \multicolumn{6}{|l|}{ Inbreeding study } \\
\hline \multicolumn{6}{|l|}{$3 \times 3 \mathrm{~m}$} \\
\hline \multirow[t]{2}{*}{ Allsweet } & Clinton & 53 & 16 & 64 & 44 \\
\hline & Kinston & 65 & 28 & 41 & 45 \\
\hline \multirow[t]{2}{*}{ Mickylee } & Clinton & 60 & 25 & 63 & 49 \\
\hline & Kinston & 66 & 29 & 52 & 49 \\
\hline Mean & & 61 & 25 & 55 & $47 \mathrm{a}^{\mathrm{y}}$ \\
\hline \multicolumn{6}{|l|}{$6 \times 6 \mathrm{~m}$} \\
\hline \multirow[t]{2}{*}{ Allsweet } & Clinton & 85 & 24 & 69 & 59 \\
\hline & Kinston & 71 & 32 & 58 & 54 \\
\hline \multirow[t]{2}{*}{ Mickylee } & Clinton & 42 & 21 & 68 & 44 \\
\hline & Kinston & 70 & 36 & 75 & 60 \\
\hline Mean & & 67 & 28 & 68 & $54 \mathrm{~b}$ \\
\hline Overall mean by year & & $64 \mathrm{a}$ & $26 \mathrm{~b}$ & $61 \mathrm{a}$ & \\
\hline F ratio & & & & & \\
\hline Year & $41.77 * * *$ & & & & \\
\hline Spacing & $734.02 *$ & & & & \\
\hline Location & $23.10 \mathrm{NS}$ & & & & \\
\hline Cultivar & $5.07 \mathrm{NS}$ & & & & \\
\hline
\end{tabular}

Intercrossing study

$1.2 \times 0.3 \mathrm{~m}$

Allsweet

Mickylee

Mean

Cross-pollination (\%)

$1.2 \times 0.6 \mathrm{~m}$

Allsweet

Mickylee

Mean

Overall mean

F ratio

Spacing $\quad 0.07 \mathrm{NS}$

Cultivar $1.29 \mathrm{NS}$

${ }^{\mathrm{z}}$ Data were averaged over two blocks of one plant per hill, trained in spiral. $\%=$ percentage of non-spotted plants out of total in progeny plots. Percentage of non-spotted plants indicated the rate of self-pollination. ${ }^{y}$ Any two means within a row or column not followed by same letter are significantly different at $P \leq 0.05$. NS, $* * *, * * *$ Nonsignificant or significant at $P \leq 0.05,0.01$, or 0.001 , respectively. 
(2010) at four locations. Each location was considered as one replication. Spacing and cultivar did not affect the rate of crosspollination in watermelon (Table 1). Similarly, there was no interaction effect $(P \geq 0.05)$ for cultivar and in-row spacing. This indicated that in-row spacing had a similar effect regardless of the cultivar. However, data are presented for both spacing and cultivar to show the variation over treatments.

At $1.2 \times 0.3-\mathrm{m}$ spacing, $31 \%$ of the seed set was the result of cross-pollination, whereas it was $33 \%$ in $1.2 \times 0.6-\mathrm{m}$ spacing (Table 2 ). 'Mickylee' had higher cross-pollination but not significantly different from 'Allsweet' at both plant spacings. Based on these results, cross-pollination was not high enough to intercross tightly spaced plants.

Overall, results of both the studies indicated that it was not possible to achieve either adequate self-pollination in widely spaced plants or cross-pollination in tightly spaced plants to make use of in a lowresource breeding program. The actual rate also varied widely with year. However, results indicated that there was a significant amount of self-pollination in watermelon that should be considered when estimating genetic variances in breeding populations.

\section{Discussion}

Year of testing and in-row spacing had a significant effect on the rate of self-pollination in watermelon in the inbreeding study. The rate of self-pollination varied slightly over cultivars and locations but greatly over years. Such large variations in the rate of self-pollination show that breeders should be cautious when interpreting the rate of self-pollination in watermelon. Environment has a large effect on pollen movement and sex expression in cucurbit crops. Pollinator activity and staminate-to-pistillate-flower ratio, which affect the rate of natural self-pollination or outcrossing, are highly dependent on environmental conditions (Kalbarczyk, 2009; Robinson and Decker-Walters, 1997). For example, high temperature, high light intensity, and long daylength promote an increase in the proportion of staminate flowers. Conversely, low temperature, low light intensity, and short daylength increase the proportion of pistillate flowers (Atsmon, 1968; Friedlander et al., 1977). A high number of staminate flowers results in increased pollen flow across plots, thereby increasing the outcrossing and minimizing the self-pollination. Wind velocity and rainy weather at the time of flowering may hinder pollinators and change pollen

Table 3. Temperature and precipitation data in Clinton and Kinston, NC, in the springs of 2009 to 2011.

\begin{tabular}{|c|c|c|c|c|c|c|c|c|}
\hline \multirow[b]{3}{*}{ Yr/location } & \multicolumn{4}{|c|}{ May } & \multicolumn{4}{|c|}{ June } \\
\hline & \multicolumn{2}{|c|}{ Clinton } & \multicolumn{2}{|c|}{ Kinston } & \multicolumn{2}{|c|}{ Clinton } & \multicolumn{2}{|c|}{ Kinston } \\
\hline & $\overline{\mathrm{Temp}}\left({ }^{\circ} \mathrm{C}\right)$ & PT (mm) & $\overline{\mathrm{Temp}\left({ }^{\circ} \mathrm{C}\right)}$ & $\overline{\mathrm{PT}}(\mathrm{mm})$ & $\overline{\text { Temp }\left({ }^{\circ} \mathrm{C}\right)}$ & $\overline{\text { PT }(\mathrm{mm})}$ & $\overline{\mathrm{Temp}}\left({ }^{\circ} \mathrm{C}\right)$ & PT (mm) \\
\hline 2009 & 27 & 2.8 & 27 & 2.1 & 32 & 2.0 & 33 & 3.8 \\
\hline 2010 & 31 & 5.0 & 28 & 2.8 & 33 & 4.3 & 34 & 4.3 \\
\hline 2011 & 31 & 2.0 & 28 & 0.6 & 33 & 2.5 & 34 & 2.5 \\
\hline
\end{tabular}

$\mathrm{PT}=$ precipitation.

movement in the field. However, temperature and rainfall data recorded (Table 3 ) at the time of flowering did not show much variation over the years except 2010 had more rainfall. However, other factors such as light intensity, humidity, soil conditions, and placement of beehives also affect pollination (not measured in this experiment) (Sedgley and Buttrose, 1978; Walters, 2005).

Unlike years, locations did not have much effect on the rate of self-pollination in this experiment. Average temperature was similar in Clinton and Kinston during the active flowering period (May and June) over multiple years (Table 3 ). However, other locations may produce greater variation in the rate of self-pollination. Self-pollination has been reported to vary from $23 \%$ to $77 \%$ over locations in cucumber (Wehner and Jenkins, 1985). A large variability exists in watermelon cultivars for staminate-to-pistillateflower ratio and for pollen production, which might affect the rate of self-pollination (Lesley, 1924; Stanghellini and Schultheis, 2005). However, our results indicated that the mating behavior was similar for "Allsweet' and 'Mickylee' although they were chosen for their large differences in fruit morphology.

Spacing had a large effect on the rate of self-pollination in watermelon in the inbreeding study. This is because pollen is generally carried short distances in cucurbits (Handel, 1982, 1983; Handel and Mishkin, 1984; Hokanson et al., 1997a, 1997b; Walters and Schultheis, 2009). Most of the pollen grains are deposited on the nearest available flower and pollen availability is diluted as the distance from the pollen donor is increased (Cresswell et al., 1995), although a small amount of pollen may be transferred longer distances $(5$ to $10 \mathrm{~m}$ ). However, $\approx 50 \%$ selfpollination was achieved in watermelon plants trained in a spiral and planted at recommended $(3 \times 3 \mathrm{~m})$ or wider $(6 \times 6 \mathrm{~m})$ plant spacing. The rate of self-pollination might be slightly overestimated as a result of field plot design. Both 'Mickylee' and 'Allsweet' have green foliage (without marker $S p$ allele) and outcrossing between them, if any, within the same plot might have been estimated as selfpollination. However, results obtained were enough to draw the conclusion that the rate of self-pollination is less than optimum as compared with self-pollinated crops. The objective of this study was to determine the rate of self-pollination at recommended $(3 \times 3 \mathrm{~m})$ and increased spacing $(6 \times 6 \mathrm{~m})$. If the rate of self-pollination is high ( $95 \%$ or greater),

HortScience Vol. 48(8) August 2013 individual plant selection can be practiced in a segregating population in pedigree breeding without the need for controlled pollination. The results indicated that although the rate of self-pollination increased from $47 \%$ to $53 \%$ by increasing plant spacing, it was insufficient to practice individual plant selection in open-field conditions except perhaps for the first generation of selection. Increasing plant spacing more than $6 \times 6 \mathrm{~m}$ would not be economically feasible for a breeding program. These results suggested that breeding methods used in self-pollinated crops may not be applicable in watermelon.

In intercrossing study, spacing did not affect the rate of outcrossing. Recurrent selection is used in maize in population improvement by intercrossing families by open-pollination and selecting the best plants (Hallauer and Miranda, 1988). Maize is a cross-pollinated crop with greater than $50 \%$ natural outcrossing. In watermelon, however, close plant spacing $(1.2 \times 0.3 \mathrm{~m}$ and $1.2 \times 0.6 \mathrm{~m})$ resulted in $31 \%$ to $35 \%$ outcrossing with a maximum of $49 \%$, less than optimum for a recurrent selection to improve quantitative traits.

Watermelon breeders often estimate genetic variances and covariances among families (e.g., half-sibs) in their populations. However, the estimates will be biased if the mating system is not known, for example in watermelon with both self- and crosspollination. The coancestry of individuals is higher when there is self-pollination. The results of this study support this concept that there is a significant amount of self-pollination in watermelon. Genetic variance can be estimated according to Weir and Cockerham (1977) as:

$$
\begin{aligned}
\sigma_{\mathrm{G}}^{2}= & (1+\mathrm{F}) \sigma_{\mathrm{A}}^{2}+(1-\mathrm{F}) \sigma_{\mathrm{D}}^{2}+4 \mathrm{FD}_{1} \\
& +4 \mathrm{FD}_{2}+\mathrm{F}(1-\mathrm{F}) \mathrm{H}
\end{aligned}
$$

where $F, \sigma_{A}^{2}, \sigma_{D}^{2}, D_{1}, D_{2}$, and $H$ are inbreeding coefficient, additive variance, dominance variance, covariance between additive and homozygous variance effects, variance of homozygous dominance effects, and measure of inbreeding depression, respectively. On the basis of this study, we recommend that watermelon breeders take into account the self-pollination rate of populations at the spacing that they are using in their breeding plots when estimating genetic variances (Ferreira et al., 2000, 2002; Kumar, 2009; Kumar and Wehner, 2011).

\section{Conclusions}

Watermelon breeders using recurrent selection to improve populations should be aware that the intercross block where they are using open-pollination of the selected individuals or families will have a significant amount of self-pollination occurring. In addition, watermelon breeders using openpollination of single-plant hills in the $F_{2}$ generation of a cross will be advancing their selections with $46 \%$ to $53 \%$ outcrossing. Hence, controlled pollination is recommended to watermelon breeders for maximum genetic gain. 


\section{Literature Cited}

Allard, R.W. 1999. Principles of plant breeding. 2nd Ed. Wiley, New York, NY.

Atsmon, D. 1968. The interaction of genetic, environmental, and hormonal factors in stem elongation and floral development of cucumber plants. Ann. Bot. (Lond.) 32:877-882.

Chowdhury, M.A. and A.E. Slinkard. 1997. Natural outcrossing in grasspea. J. Hered. 88:154156.

Collevatti, R.G., J.H. Schoereder, and L.A.O. Campos. 2000. Foraging behavior of bee pollinators on the tropical weed Triumfetta semitriloba: Flight distance and directionality. Rev. Bras. Biol. 60:29-37.

Cresswell, J.E., A.P. Bassom, S.A. Bell, S.J Collins, and T.B. Kelly. 1995. Predicted pollen dispersal by honey-bees and three species of bumble-bees foraging on oil seed rape: A comparison of three models. Funct. Ecol. 9:829841.

Delaplane, K.S. and D.F. Mayer. 2000. Cross pollination by bees. CABI, Oxon, UK.

Fehr, W.R. 1993. Principles of cultivar development. Vol. 1. McMillan, New York, NY.

Ferreira, M.A.J. da.F., M.A. de Queiroz, R. Vencosky, L.T. Braz, M.L.C. Vieira, and R.M.E. Borges. 2002. Sexual expression and mating system in watermelon: Implications for breeding programs. Crop Breeding \& Appl. Biotechnol. $2: 39-48$.

Ferreira, M.A.J. da.F., R. Vencosky, M.L.C. Vieira, and M.A. de Queiroz. 2000. Outcrossing rate and implications for the improvement of a segregating population of watermelon Acta Hort. 510:47-54.

Free, J.B. 1993. Insect pollination of crops. 2nd Ed. Academic Press, London, UK.

Friedlander, M., D. Atsmon, and E. Galun. 1977. The effects of abscisic acid and other growth regulators on various sex genotypes. Plant Cell Physiol. 18:261-269.

Gingras, D., J. Gingras, and D. Oliveira. 1999. Visits of honeybees (Hymenoptera: Apidae) and their effects on cucumber yields in the field. J. Econ. Entomol. 92:435-438.

Guner, N. and T.C. Wehner. 2004. The genes of watermelon. HortScience 39:1175-1182.

Gusmini, G. and T.C. Wehner. 2007. Heritability and genetic variance estimates for fruit weight in watermelon. HortScience 42:13321336.

Hallauer, A.R. and J.B. Miranda. 1988. Quantitative genetics in maize breeding. 2nd Ed. Iowa State Univ. Press, Ames, IA.
Handel, S.N. 1982. Dynamics of gene flow in an experimental population of Cucumis melo (Cucurbitaceae). Amer. J. Bot. 69:15381546.

Handel, S.N. 1983. Contrasting gene flow patterns and genetic subdivision in adjacent populations of Cucumis sativus (Cucurbitaceae). Evolution 37:760-771.

Handel, S.N. and J.L.V. Mishkin. 1984. Temporal shifts in gene flow and seed set: Evidence from an experimental population of Cucumis sativus. Evolution 38:1350-1357.

Harding, J. and C.L. Tucker. 1964. Quantitative studies on mating systems. I. Evidence for nonrandomness of outcrossing in Phaseolus lunatus. Heredity 19:369-381.

Hokanson, S.C., J.F. Hancock, and R. Grumet 1997a. Direct comparison of pollen-mediated movement of native and engineered genes. Euphytica 96:396-403.

Hokanson, S.C., R. Grumet, and J.F. Hancock. 1997b. Effect of border rows and trap/donor ratios on pollen-mediated gene movement Ecol. Appl. 7:1075-1081.

Jain, S.K. 1976. Population structure and the effects of pollinating system, p. 15-36. In Frankel, O.H. and J.G. Hawkes (eds.). Crop genetic resources for today and tomorrow. Cambridge Univ. Press, Cambridge, UK.

Jenkins, J.M., Jr. 1942. Natural self-pollination in cucumbers. Proc. Amer. Soc. Hort. Sci. 40 411-412.

Kalbarczyk, R. 2009. Potential reduction in cucumber field (Cucumis sativus L.) in Poland caused by unfavorable thermal conditions of the soil. Acta Scientiarum Polonorum Hortorum Cultus 8:45-58.

Kumar, R. 2009. Inheritance of fruit yield and other horticulturally important traits watermelon [Citrullus lanatus (Thumb.) Matsum. \& Nakai]. PhD diss., NC State Univ., Raleigh, NC.

Kumar, R. and T.C. Wehner. 2011. Natural outcrossing in watermelon-A review. Cucurbit Genet. Coop. Rpt. 33/34:42-43.

Lesley, J.W. 1924. Cross-pollination of tomatoes: Varietal differences in amount of natural crosspollination. J. Hered. 15:233-235.

Martin, A., C. Troadec, A. Boualem, M. Rajab, R. Fernandez, H. Morin, M. Pitrat, C. Dogimont, and A. Bendahmane. 2009. A transposoninduced epigenetic change leads to sex determination in melon. Nature 461:1135-1138.

McGregor, S.E. 1976. Insect pollination of cultivated crops. USDA-NRCS Agr. Hdbk. 496. U.S. Gov. Print. Office, Washington, DC.
Neppl, G.P. and T.C. Wehner. 2001. Survey of watermelon trialing methods used by breeders in the United States. Cucurbit Genet. Coop. Rpt. 24:68-70.

Poole, C.F. 1944. Genetics of cultivated cucurbits. J. Hered. 35:122-128.

Rhodes, B. and F. Dane. 1999. Gene list for watermelon. Cucurbit Genet. Coop. Rpt. 22:61-77.

Rhodes, B. and X. Zhang. 1995. Gene list for watermelon. Cucurbit Genet. Coop.Rpt. 18:6984.

Rhodes, B.B. 1986. Genes affecting foliage color in watermelon. J. Hered. 77:134-135.

Robinson, R.W. and D.S. Decker-Walters. 1997. Cucurbits. CABI, New York, NY.

Sanders, D.C. 2004. Vegetable crop guidelines for the Southeastern U.S. 2004-2005. North Carolina Veg. Growers Assn., Raleigh, NC.

Sedgley, M. and M.S. Buttrose. 1978. Some effects of light intensity, daylength and temperature on flowering and pollen tube growth in the watermelon (Citrullus lanatus). Ann. Bot. (Lond.) 43:609-616.

Stanghellini, M.S. and J.R. Schultheis. 2005. Genotypic variability in staminate flower and pollen grain production of diploid watermelons. HortScience 40:752-755.

Walters, S.A. 2005. Honey bee pollination requirements for triploid watermelon. HortScience 40:1268-1270

Walters, S.A. and J.R. Schultheis. 2009. Directionality of pollinator movements in watermelon plantings. HortScience 44:49-52.

Wehner, T.C. 2002. Vegetable cultivar descriptions for North America. List 26-2002. HortScience $37: 15-78$

Wehner, T.C. 2008. Watermelons, p. 381-418. In: Prohens, J. and F. Nuez (eds.). Handbook of plant breeding; Vegetables I: Asteraceae, Brassicaceae, Chenopodiaceae, and Cucurbitaceae. Springer, New York, NY.

Wehner, T.C. and C.S. Cramer. 1996. Ten cycles of recurrent selection for fruit yield, earliness, and quality in three slicing cucumber populations. J. Amer. Soc. Hort. Sci. 121:362-366.

Wehner, T.C. and S.F. Jenkins, Jr. 1985. Rate of natural outcrossing in monoecious cucumbers. HortScience 20:211-213.

Weir, B.S. and C.C. Cockerham. 1977. Two-locus theory in quantitative genetics, p. 247-269. In: Pollak, E., O. Kempthorne, and T.B. Bailey, Jr. (eds.). Proc. Intl. Conf. Quantitative Genetics, Ames, IA, 16-21 August. Iowa State Univ. Press, Ames, IA.

Zimmerman, M. 1979. Optimal foraging: A case for random movement. Oecologia 43:261-267. 